\title{
JOES $\begin{aligned} & \begin{array}{l}\text { Journal } \\ \text { of Educational } \\ \text { Study }\end{array}\end{aligned}$ \\ ISSN 2798-0650 \\ Volume 1 Issue 32021 \\ DOI: $10.36663 /$ joes.v1i3.204 \\ Exploring Readiness of Teachers Toward English Remote Teaching
}

Ni Luh Ayu Gunawati Karuniasih, Universitas Pendidikan Ganesa, Indonesia ayu.gunawati166@gmail.com

\begin{abstract}
Remote English teaching becomes a trend during the pandemic of Covid-19 outbreak. Schools in Indonesia are forced to conduct teaching and learning activity remotely during Work from Home (WFH) regulation. However, not all teachers were ready to teach virtually. This study aimed at investigating the teachers' and students' readiness toward remote English teaching. The subject were the English teachers at SMAN 1 Kubutambahan. An explanatory sequential mixed-method design was implemented in this research. The data were collected through an online survey and followed up with an interview. The data were collected through an online survey and analysed using Ideal Mean score analysis. The survey used a questionnaire which contain four dimensions, namely technology, innovation, people, and self-development to investigate the teachers' and students' readiness level. The research finding showed that English teachers were categorized in the ready category, which means they were ready in conducting remote English teaching. The result of this research can be used as an evaluation for the teacher in order to improve their readiness level in the future.
\end{abstract}

Keywords: Remote English Teaching, Teachers'Readiness.

\section{Introduction}

Over the past several decades, technology has developed and become a need for people in many aspects such as communication, industry, and education. According to Ahmad (2012), technology makes a revolution in the teaching and learning process which makes remote teaching possible to be conducted. The essence of remote teaching is teaching that is done by using internet facilities with help from various technology that is done online (Fauzi et al., 2020). Even though remote teaching is done online, it is slightly different from online learning. Furthermore, it is also explained that online learning emphasizes the use of technology and media that are available online synchronously or asynchronously. Remote teaching is more emphasized in the teaching activity conducted online, which is majorly conducted synchronously. However, the main point of remote teaching is not only to make the teacher and student interact with the technology, but also to make the teaching and learning process meaningful. During the pandemic, schools in Indonesia are forced to conduct the teaching and learning process remotely. However, remote teaching is not always running as well as expected due to the lack of readiness of the teachers during the teaching 


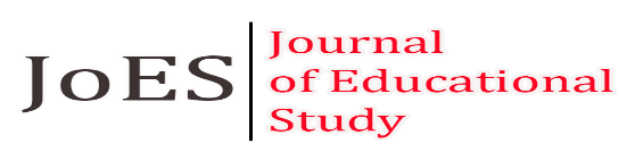

ISSN 2798-0650

Volume 1 Issue 32021

DOI: $10.36663 /$ joes.v1i3.204

and learning process (Churiyah et al., 2020; Martiana, 2019). Widyanti and Park (2020) conducted a study on some universities in developing countries which shows that teacher' readiness in online teaching should be improved to make the material acceptable for learners. Another study conducted by Fauzi et al. (2020) at Banten and West Java region shows that online learning is not running as well as expected due to the readiness of the teacher and students.

Many researches were showing that learning through online platforms is not running well due to lack of preparation and planning. Not all teachers are fully integrated with technology for teaching virtual class which makes teachers facing difficulties during remote teaching (Champa et al., 2019; Hung, 2016; Lee, 2020; Nugroho \& Atmojo, 2020). It is contradictive with the expectation where learning through virtual platform gives space to allow deep learning to evolve within discussion forums and paved a way to explore more for the students. However, students rate online courses lower than face-to-face courses. Students expect the instructor to be more effective in giving instructions which shows that the teacher cannot fulfil the expectation of the students in the online class (Lowenthal et al., 2015; Shearer et al., 2015; Young, 2010). The readiness level of the teachers is affected by the challenges faced by the teacher (Nicklin et al., 2016; Widodo et al., 2020). The challenges faced by the teachers are not only about the technical skill but also the experience of the teachers, material appropriateness, learning planning, and material design and development (Besser et al., 2020; Gao \& Zhang, 2020; Lee, 2020; Tejedor et al., 2021). Those problems also appear in the teaching and learning process at SMAN 1 Kubutambahan. Through a preliminary observation, it was found that the teacher faced difficulty in using technology for learning. The teacher found it hard to adapt to the changes from face-toface class to full virtual class. Based on those problems, this study is conducted to see the readiness level of the teacher at SMAN 1 Kubutambahan.

\section{Method}

In seeking the teachers' readiness level, this study applied descriptive quantitative analysis to gain the result. Four English teacher in SMAN 1 Kubutambahan were involved as the sample and the data were gained through an online survey. Questionnaire in form of five-point Likert scale were used in this survey. The questionnaire were adapted from e-learning theory by Aydin and Tasci (2005). In collecting the data, some procedures were used in this research. Firstly, preliminary research about SMAN 1 Kubutambahan was conducted to observe how the teaching and learning process. Secondly, the sample was chosen using simple random sampling to investigate the students' readiness level and involve all English teachers at SMAN 1 Kubutambahan. The next was surveying online platforms. After the data were collected, the data were ready to be analyzed. The data from the survey were analyzed using the SPSS program through descriptive statistics, central tendency measurement (mean), and dispersion measurement (standard deviation). Descriptive statistical analysis was conducted to measure the ideal mean score. 


\section{JOES $\begin{aligned} & \begin{array}{l}\text { Journal } \\ \text { of Educational } \\ \text { Study }\end{array}\end{aligned}$}

ISSN 2798-0650

Volume 1 Issue 32021

\section{Findings}

\section{DOI: $10.36663 /$ joes.v1i3.204}

The survey for teachers was using a questionnaire containing 20 items based on four dimensions. The questionnaire had been translated before it was spread out to the teachers. The questionnaire was distributed to all English teachers at SMAN 1 Kubutambahan through online social media connected to the online form. Four English teachers filled the questionnaire. The data calculation result could be seen in Table 1.

Table 1.Descriptive Statistics Data of Questionnaire for Teacher

\begin{tabular}{|c|c|c|}
\hline \multicolumn{2}{|c|}{ Statistics } \\
\hline \multicolumn{2}{|c|}{ Teachers' Readiness } \\
\hline \multirow{2}{*}{$\mathrm{N}$} & Valid & 4 \\
\cline { 2 - 3 } & Missing & 0 \\
\hline Mean & 67.75 \\
\hline Std. Error of Mean & 1.652 \\
\hline Median & 68.00 \\
\hline Mode & $64^{\mathrm{a}}$ \\
\hline Std. Deviation & 3.304 \\
\hline Variance & 10.917 \\
\hline Range & 7 \\
\hline Minimum & 64 \\
\hline Maximum & 71 \\
\hline
\end{tabular}

The table above described the descriptive data of the questionnaire. From the table above, it can be seen that the mean score of teachers' readiness toward remote English teaching was 67.75. The highest score of the teacher was 71 from 100 (20x5), and the lowest score was 64 from 20 (20x1). The data of the mean score of teachers' readiness toward Remote English teaching was classified into five categories, namely very ready, ready, quite ready, not quite ready, and not ready. To determine the mean score of the Teacher, Mean Ideal (Mi) and Standard Deviation Ideal (SDi) were measured. The formulas can be seen as below:

$$
\begin{array}{ll}
\mathrm{Mi} & =1 / 2(\text { ideal Max. Score }+ \text { ideal Min. Score }) \\
\mathrm{Mi} & =1 / 2(100+20) \\
=60 & \\
\text { SDi } & =1 / 6(\text { ideal Max. Score }- \text { ideal Min. Score }) \\
\text { SDi }=1 / 6(100-20) & \\
=13.33
\end{array}
$$




\section{JOES $\mid \begin{aligned} & \text { Journal } \\ & \text { of Educational } \\ & \text { Study }\end{aligned}$}

ISSN 2798-0650

Volume 1 Issue 32021

DOI: $10.36663 /$ joes.v1i3.204

Based on the calculation, it can be stated that the mean ideal (Mi) of the questionnaire was 60 , and the standard deviation ideal was 13.33. The categorization of mean score of teachers' readiness toward Remote English teaching was presented in Table 2.

Table 1. Categorization of Mean Score of Teachers' Readiness Toward Remote English teaching

\begin{tabular}{|l|l|l|l|l|}
\hline No. & Criteria & Interval & Categorization & Qualification \\
\hline 1. & $\begin{array}{l}\mathrm{MI}+1.5 \quad \text { SDI } \\
<\mathrm{M}<\mathrm{Mi}+3.0 \mathrm{SDi}\end{array}$ & $79.99<\mathrm{M}<99.9$ & Very high & Very ready \\
\hline 2. & $\begin{array}{l}\mathrm{MI}+0.5 \mathrm{SDI}<\mathrm{M}<\mathrm{MI}+1.5 \\
\text { SDI }\end{array}$ & $66.66<\mathrm{M}<79.99$ & High & Ready \\
\hline 3. & $\begin{array}{l}\text { MI-0.5 SDI }<\mathrm{M}<\mathrm{MI}+0.5 \\
\text { SDI }\end{array}$ & $53.33<\mathrm{M}<66.66$ & Average & Quite Ready \\
\hline 4. & $\begin{array}{l}\text { MI-1.5 SDI }<\mathrm{M}<\mathrm{MI}-0.5 \\
\text { SDI }\end{array}$ & $40<\mathrm{M}<53.33$ & Low & $\begin{array}{l}\text { Not Quite } \\
\text { Ready }\end{array}$ \\
\hline 5. & $\begin{array}{l}\text { MI-3.0 SDI }<\mathrm{X}<\mathrm{MI}-1.5 \\
\text { SDI }\end{array}$ & $20.01<\mathrm{M}<40$ & Very low & Not Ready \\
\hline
\end{tabular}

Table 2 presented the mean score of the teachers' readiness toward Remote English teaching was in the ready category with the mean score was 66.75 and it was in the interval $66.66<\mathrm{M}<79.99$. It can be inferred that the English teachers at SMAN 1 Kubutambahan were ready in conducting Remote English teaching. Moreover, the readiness of the English teachers was also analysed based on each dimension, namely technology, innovation, people, and self-development dimension. The technology dimension explained the teachers' ability and attitude toward technology that was used during remote teaching. The descriptive data of the technology perceiver dimension was presented in Table 3.

Table 2. Descriptive Statistics Data of Technology Dimension

\begin{tabular}{|c|c|c|}
\hline \multicolumn{3}{|c|}{ Statistics } \\
\hline \multicolumn{3}{|c|}{ Technology Dimension } \\
\hline $\mathrm{N}$ & Valid & 4 \\
\cline { 2 - 3 } & Missing & 0 \\
\hline Mean & 35.25 \\
\hline Median & 35.00 \\
\hline Mode & $33^{\mathrm{a}}$ \\
\hline Std. Deviation & 2.217 \\
\hline Variance & 4.917 \\
\hline Range & 5 \\
\hline Minimum & 33 \\
\hline Maximum & 38 \\
\hline
\end{tabular}




\section{JOES $\mid \begin{aligned} & \text { Journal } \\ & \text { of Educational } \\ & \text { Study }\end{aligned}$}

ISSN 2798-0650

Volume 1 Issue 32021

DOI: $10.36663 /$ joes.v1i3.204

Table 3 presented the mean score of the teachers in the technology dimension was 35.25 , with the maximum score is 38 from 50 (10x5) and the minimum score was 33 from 10 (10x1). The mean score of the teachers' readiness toward Remote English teaching context, especially in technology dimension, was classified into five categories: ready, ready, quite ready, not quite ready, and not ready. In categorizing the mean score of the teaches' readiness toward Remote English teaching context, Mean Ideal (Mi) and Standard Deviation (SDi) were measured with formulas presented below:

$$
\begin{array}{ll}
\mathrm{Mi} & =1 / 2(\text { ideal Max. Score }+ \text { ideal Min. Score }) \\
\mathrm{Mi} & =1 / 2(50+10) \\
=30 & \\
\mathrm{SDi} & =1 / 6(\text { ideal Max. Score }- \text { ideal Min. Score }) \\
\mathrm{SDi} & =1 / 6(50-10) \\
=6.66 &
\end{array}
$$

The result of the calculation above showed that the Mean Ideal (Mi) of the technology dimension was 30, and the Standard Deviation Ideal (SDi) was 6.66. The categorization of the technology dimension can be seen in Table 4.

Table 3. Categorization of Mean Score Technology Dimension

\begin{tabular}{|c|c|c|c|c|}
\hline No. & Criteria & Interval & Categorization & Qualification \\
\hline 1. & $\begin{array}{c}\mathrm{MI}+1.5 \mathrm{SDI} \\
\mathrm{M}<\mathrm{Mi}+3.0 \mathrm{SDi}\end{array}$ & $39.99<\mathrm{M}<49.98$ & Very high & Very ready \\
\hline 2. & $\begin{array}{c}\mathrm{MI}+0.5 \\
\mathrm{SDI}<\mathrm{M}<\mathrm{MI}+1.5 \mathrm{SDI}\end{array}$ & $33.33<\mathrm{M}<39.99$ & High & Ready \\
\hline 3. & $\begin{array}{c}\mathrm{MI}-0.5 \mathrm{SDI}<\mathrm{M}<\mathrm{MI}+0.5 \\
\mathrm{SDI}\end{array}$ & $26.67<\mathrm{M}<33.33$ & Average & Quite Ready \\
\hline 4. & $\begin{array}{c}\text { MI-1.5 SDI }<\mathrm{M}<\mathrm{MI}-0.5 \\
\text { SDI }\end{array}$ & $20.01<\mathrm{M}<26.67$ & Low & $\begin{array}{c}\text { Not Quite } \\
\text { Ready }\end{array}$ \\
\hline 5. & $\begin{array}{c}\text { MI-3.0 SDI }<\mathrm{X}<\mathrm{MI}-1.5 \\
\text { SDI }\end{array}$ & $10.02<\mathrm{M}<20.01$ & Very low & Not Ready \\
\hline
\end{tabular}

Table 4 presented the categorization of the mean score of the technology dimension. The mean score of the teacher in the technology dimension was 35.25, which was categorized in the ready category, and it was in the interval $33.33<\mathrm{M}<39.99$. Based on the result, it can be inferred that the English teachers in SMAN 1 Kubutambahan are ready to conduct remote using the technology as the tool and media. 


\section{JOES $\mid \begin{aligned} & \text { Journal } \\ & \text { of Educational } \\ & \text { Study }\end{aligned}$}

ISSN 2798-0650

Volume 1 Issue 32021

DOI: $10.36663 /$ joes.v1i3.204

The second dimension is innovation, which explains the teachers' readiness to adopt innovation and openness to innovation. The descriptive statistics of the innovation dimension was presented in Table 5.

Table 4. Descriptive Statistics Data of Innovation Dimension

\begin{tabular}{|c|c|c|}
\hline \multicolumn{3}{|c|}{ Statistics } \\
\hline \multicolumn{2}{|c|}{ Innovation Dimension } \\
\hline \multirow{2}{*}{$\mathrm{N}$} & Valid & 4 \\
\cline { 2 - 3 } & Missing & 0 \\
\hline Mean & 13.75 \\
\hline Median & 14.00 \\
\hline Mode & 14 \\
\hline Std. Deviation & 1.258 \\
\hline Variance & 1.583 \\
\hline Range & 3 \\
\hline Minimum & 12 \\
\hline Maximum & 15 \\
\hline
\end{tabular}

Table 5 presented the mean score of the teachers' readiness toward Remote English teaching, especially in the innovation dimension. The mean score was 13.75 , with the highest score was 15 from 20 (4x5), and the lowest score was 12 from 4 (4x1). The classification of the mean score was divided into five categories, namely very ready, ready, quite ready, not quite ready, and not ready.To categorize the mean score of the teaches' readiness toward Remote English teaching context, Mean Ideal (Mi) and Standard Deviation (SDi) were measured using formulas below:

$$
\begin{array}{ll}
\mathrm{Mi} & =1 / 2(\text { ideal Max. Score }+ \text { ideal Min. Score }) \\
\mathrm{Mi} & =1 / 2(20+4) \\
=12 & \\
\text { SDi } & =1 / 6(\text { ideal Max. Score }- \text { ideal Min. Score }) \\
\text { SDi } & =1 / 6(20-4) \\
=2.67 &
\end{array}
$$

Based on the calculation above, it can be seen that the Mean Score Ideal (Mi) of the innovation dimension was 12, and the Standard Deviation Ideal (SDi) was 2.67. The categorization of the innovation dimension was presented in Table 6. 
JOES $\begin{aligned} & \begin{array}{l}\text { Journal } \\ \text { of Educational } \\ \text { Study }\end{array} \\ & \text { Studion }\end{aligned}$

ISSN 2798-0650

Volume 1 Issue 32021

DOI: 10.36663/joes.v1i3.204

Table 5. Categorization of Innovation Dimension

\begin{tabular}{|c|c|c|c|c|}
\hline No. & Criteria & Interval & Categorization & Qualification \\
\hline 1. & $\begin{array}{c}\mathrm{MI}+1.5 \mathrm{SDI} \\
<\mathrm{M}<\mathrm{Mi}+3.0 \mathrm{SDi}\end{array}$ & $16<\mathrm{M}<20.01$ & Very high & Very ready \\
\hline 2. & $\begin{array}{c}\mathrm{MI}+0.5 \\
\mathrm{SDI}<\mathrm{M}<\mathrm{MI}+1.5 \mathrm{SDI}\end{array}$ & $13.34<\mathrm{M}<16$ & High & Ready \\
\hline 3. & $\begin{array}{c}\mathrm{MI}-0.5 \mathrm{SDI}<\mathrm{M}<\mathrm{MI}+0.5 \\
\mathrm{SDI}\end{array}$ & $10.67<\mathrm{M}<13.34$ & Average & Quite Ready \\
\hline 4. & $\begin{array}{c}\text { MI-1.5 SDI }<\mathrm{M}<\mathrm{MI}-0.5 \\
\text { SDI }\end{array}$ & $7.99<\mathrm{M}<10.67$ & Low & $\begin{array}{c}\text { Not Quite } \\
\text { Ready }\end{array}$ \\
\hline 5. & $\begin{array}{c}\text { MI-3.0 SDI }<\mathrm{X}<\mathrm{MI}-1.5 \\
\text { SDI }\end{array}$ & $3.99<\mathrm{M}<7.99$ & Very low & Not Ready \\
\hline
\end{tabular}

Based on Table 6, it can be seen that the categorization of innovation dimension of English teacher toward Remote English teaching context was in the ready category within the interval $13.34<\mathrm{M}<16$ because the mean score was 13.75 . Based on the result, it can be inferred that the English teachers at SMAN 1 Kubutambahan were ready to adopt the innovation and had an openness to innovation.

The third dimension was the people dimension, which explains teachers' experience and ability to use and accept technology in remote teaching. Three items are included in this dimension. The descriptive statistics of the people dimension are presented in Table 7.

Table 6. Descriptive Statistics of People Dimension

\begin{tabular}{|c|c|c|}
\hline \multicolumn{2}{|c|}{ Statistics } \\
\hline \multicolumn{2}{|c|}{ People Dimension } \\
\hline \multirow{2}{*}{$\mathrm{N}$} & Valid & 4 \\
\cline { 2 - 3 } & Missing & 0 \\
\hline Mean & 8.50 \\
\hline Median & 8.50 \\
\hline Mode & $7^{\mathrm{a}}$ \\
\hline Std. Deviation & 1.291 \\
\hline Variance & 1.667 \\
\hline Range & 3 \\
\hline Minimum & 7 \\
\hline Maximum & 10 \\
\hline
\end{tabular}




\section{JOES $\begin{aligned} & \begin{array}{l}\text { Journal } \\ \text { of Educational } \\ \text { Study }\end{array}\end{aligned}$}

ISSN 2798-0650

Volume 1 Issue 32021

DOI: $10.36663 /$ joes.v1i3.204

Table 7 showed the descriptive statistics of the teachers' readiness toward Remote English teaching in the people dimension. The result showed that the mean score $(\mathrm{M})$ of the data was 8.50 , with the maximum score was 10 from $15(3 \times 5)$, and the minimum score was 7 from $3(3 \times 1)$. The classification of the mean score was classified into five categories namely very ready, ready, quite ready, not quite ready, and not ready. The Mean Score Ideal (Mi) and Standard Deviation Ideal (SDi) were measured to categorize the readiness level in the people dimension. The result was calculated using the formulas below:

$$
\begin{array}{ll}
\mathrm{Mi} & =1 / 2(\text { ideal Max. Score }+ \text { ideal Min. Score }) \\
\mathrm{Mi} & =1 / 2(15+3) \\
=9 & \\
\text { SDi } & =1 / 6(\text { ideal Max. Score }- \text { ideal Min. Score }) \\
\text { SDi } & =1 / 6(15-3) \\
=2 &
\end{array}
$$

The calculation presented that the Mean Score Ideal (Mi) of the people dimension was 9, and the Standard Deviation Ideal (SDi) was 2. The categorization of readiness level in the people dimension can be seen in Table 8 .

Table 7. Categorization of People Dimension

\begin{tabular}{|c|c|c|c|c|}
\hline No. & Criteria & Interval & Categorization & Qualification \\
\hline 1. & $\begin{array}{c}\mathrm{MI}+1.5 \mathrm{SDI}<\mathrm{M}<\mathrm{Mi}+3.0 \\
\text { SDi }\end{array}$ & $12<\mathrm{M}<15$ & Very high & Very ready \\
\hline 2. & $\begin{array}{c}\mathrm{MI}+0.5 \mathrm{SDI}<\mathrm{M}<\mathrm{MI}+1.5 \\
\text { SDI }\end{array}$ & $10<\mathrm{M}<12$ & High & Ready \\
\hline 3. & $\begin{array}{c}\mathrm{MI}-0.5 \mathrm{SDI}<\mathrm{M}<\mathrm{MI}+0.5 \\
\mathrm{SDI}\end{array}$ & $8<\mathrm{M}<10$ & Average & Quite Ready \\
\hline 4. & $\begin{array}{c}\mathrm{MI}-1.5 \mathrm{SDI}<\mathrm{M}<\mathrm{MI}-0.5 \\
\mathrm{SDI}\end{array}$ & $6<\mathrm{M}<8$ & Low & $\begin{array}{c}\text { Not Quite } \\
\text { Ready }\end{array}$ \\
\hline 5. & $\begin{array}{c}\mathrm{MI}-3.0 \mathrm{SDI}<\mathrm{X}<\mathrm{MI}-1.5 \\
\mathrm{SDI}\end{array}$ & $3<\mathrm{M}<6$ & Very low & Not Ready \\
\hline
\end{tabular}

Table 8 showed that the categorization of people dimension of English teacher toward Remote English teaching context was in the quite ready category within the interval $8<\mathrm{M}<10$ since the mean score was 8.50. From the categorization, it can be inferred that the English teacher was had enough experience and ability in conducting remote teaching, which conducted fully online. The fourth dimension is self-development, which explains how teachers can manage their time for their self-development and how the teachers believe in self-development. There are three items in this dimension. The descriptive statistics of the self-development dimension was presented in Table 9. 


\section{JOES $\begin{aligned} & \begin{array}{l}\text { Journal } \\ \text { of Educational } \\ \text { Study }\end{array}\end{aligned}$}

ISSN 2798-0650

Volume 1 Issue 32021

DOI: $10.36663 /$ joes.v1i3.204

Table 8. Descriptive Statistics of Self-Development Dimension

\begin{tabular}{|c|c|c|}
\hline \multicolumn{2}{|c|}{ Statistics } \\
\hline \multicolumn{2}{|c|}{ Self-Development Dimension } \\
\hline \multirow{2}{*}{$\mathrm{N}$} & Valid & 4 \\
\cline { 2 - 3 } & Missing & 0 \\
\hline Mean & 10.25 \\
\hline Median & 10.50 \\
\hline Mode & 11 \\
\hline Std. Deviation & 0.957 \\
\hline Variance & 0.917 \\
\hline Range & 2 \\
\hline Minimum & 9 \\
\hline Maximum & 11 \\
\hline
\end{tabular}

Table 9 showed that the mean score of the self-development dimension was 10.25, with the highest score was 11 from $15(3 \times 5)$ and the lowest score was 9 from 3 (3x1). The classification of the mean score was divided into five categories: ready, ready, quite ready, not quite ready, and not ready. The Mean Score Ideal (Mi) and Standard Deviation Ideal (SDi) were measured to categorize the readiness level, especially in the Self-Development dimension. The result was calculated using the formulas below:

$$
\begin{array}{ll}
\text { Mi } & =1 / 2(\text { ideal Max. Score }+ \text { ideal Min. Score }) \\
\text { Mi } & =1 / 2(15+3) \\
=9 & \\
\text { SDi } & =1 / 6(\text { ideal Max. Score }- \text { ideal Min. Score }) \\
\text { SDi } & =1 / 6(15-3) \\
=2 &
\end{array}
$$

The calculation showed that the Mean Score Ideal (Mi) of the self-development dimension was 9, and the Standard Deviation Ideal (SDi) was 2. The categorization of readiness level in the self-development dimension can be seen in Table 10.

Table 9. Categorization of Self-Development Dimension

\begin{tabular}{|c|c|c|c|c|}
\hline No. & Criteria & Interval & Categorization & Qualification \\
\hline 1. & $\begin{array}{c}\mathrm{MI}+1.5 \mathrm{SDI}<\mathrm{M}<\mathrm{Mi}+3.0 \\
\text { SDi }\end{array}$ & $12<\mathrm{M}<15$ & Very high & Very ready \\
\hline 2. & $\begin{array}{c}\mathrm{MI}+0.5 \mathrm{SDI}<\mathrm{M}<\mathrm{MI}+1.5 \\
\mathrm{SDI}\end{array}$ & $10<\mathrm{M}<12$ & High & Ready \\
\hline
\end{tabular}




$$
\text { JOES } \begin{aligned}
& \begin{array}{l}
\text { Journal } \\
\text { of Educational } \\
\text { Study }
\end{array}
\end{aligned}
$$

ISSN 2798-0650

Volume 1 Issue 32021

DOI: $10.36663 /$ joes.v1i3.204

\begin{tabular}{|c|c|c|c|c|}
\hline 3. & $\begin{array}{c}\text { MI-0.5 SDI }<\mathrm{M}<\mathrm{MI}+0.5 \\
\text { SDI }\end{array}$ & $8<\mathrm{M}<10$ & Average & Quite Ready \\
\hline 4. & $\begin{array}{c}\text { MI-1.5 SDI }<\mathrm{M}<\mathrm{MI}-0.5 \\
\text { SDI }\end{array}$ & $6<\mathrm{M}<8$ & Low & $\begin{array}{c}\text { Not Quite } \\
\text { Ready }\end{array}$ \\
\hline 5. & $\begin{array}{c}\text { MI-3.0 SDI }<\mathrm{X}<\mathrm{MI}-1.5 \\
\text { SDI }\end{array}$ & $3<\mathrm{M}<6$ & Very low & Not Ready \\
\hline
\end{tabular}

Table 10 showed that the categorization of the self-development dimension of English teacher toward remote English teaching context was in the ready category with the mean score was 10.25 within the interval $10<M<12$. Based on the result, it can be inferred that the English teachers at SMAN 1 Kubutambahan were able to manage their time for their self-development and the teachers believed in self-development through learning from workshops and seeking for information for teaching the online classroom. Teachers' readiness toward Remote English teaching was in the ready category, with the mean score was 66.75 within the interval $66.66<M<79.99$. It means that the English teachers at SMAN 1 Kubutambahan were ready in conducting Remote English teaching.

After the survey data were gained, interview is conducted to seek deeper into the limiting factors during remote English teaching.he teacher's interview result describes the limiting and supporting factors from the teachers' perspective. The result of the interview is used to support the data from the survey. Three English teachers at SMAN 1 Kubutambahan were involved in this interview as the source to investigate the limiting and supporting factors of remote English teaching. From the interview, several interesting findings are revealed as follows.

\section{Connection Problem}

The first problem found was the connection problem which rarely found during the teaching and learning process. From the interview, it was found that the connection problem was not the main problems faced by the teachers. This is stated by Teacher 1 as follows.

\section{"Connection problem rarely happened in my place" (T1).}

From the statement above, it can be seen that the teacher has a good connection for teaching. A similar opinion also stated by Teacher 2 and Teacher 3 who claim that they have a good connection for teaching. However, it also found that connection problems sometimes happen when the weather is bad. This is stated by Teacher 2 and Teacher 3 as follows.

"The connection in my place is good, but sometimes there are connection problem when the weather is bad" (T2).

"My connection at home is good, but sometimes the connection is unstable in rainy day" (S3). 


\section{JOES $\begin{aligned} & \begin{array}{l}\text { Journal } \\ \text { of Educational } \\ \text { Study }\end{array} \\ & \text { Etudution }\end{aligned}$}

ISSN 2798-0650

Volume 1 Issue 32021

DOI: $10.36663 /$ joes.v1i3.204

Regarding to the result, it can be seen that the teachers generally have a good connection for teaching during Remote English teaching activity. However, it also found that the factor such as the bad weather sometimes interrupts the remote teaching process.

\section{Difficulties in Choosing the Suitable Materials for Students}

The second limiting factors found is the difficulties in choosing the suitable material and model for the student. The interview result showed that English teachers at SMAN 1 Kubutambahan found it difficult to choose a suitable learning model for the students because they were not facing their students face-to-face. It is stated by Teacher 2 as follows.

"I do not know the students' characters, so it is difficult to decide which learning model is suited well for students. For that, I attended several workshops so that I could better understand how to teach virtually." (T2).

The teacher admits that it was hard to find suitable learning material for the students during teaching and learning through an online platform. This opinion is similar to teacher 3' opinion as follows.

"Usually, I find it a bit difficult to adjust the material. It is a bit difficult to teach without knowing the character of the students through a face-to-face meeting." (T3).

Based on those responses, it can be concluded that the problem faced by the teachers during the teaching and learning process was their ability in choosing the suitable learning model for the students. Through the interview, it was found that the supporting factors were coming from their environment. It is stated by Teacher 1 as follows.

"In my opinion, my environment is supportive to carry out the Remote English teaching. My family is all doing Work from Home (WFH), so the atmosphere at home is quite conducive for teaching." (T1).

From the statement above, it can be seen that Teacher 1 found her environment is quite conducive for conducting remote teaching, which can be considered as the supporting factor for conducting remote teaching. A similar opinion also stated by Teacher 2 and Teacher 3 who claimed that the conducive environment helps them in maintaining their focus during the teaching and learning process.

"In my opinion, the environment is quite supportive. The atmosphere and situation are quiet enough for me, it helps me to be more focus on delivering learning materials." (T2).

"My environment supports the implementation of teaching learning activity. My neighbours are not noisy, so I can focus on delivering material to students." (T3). 


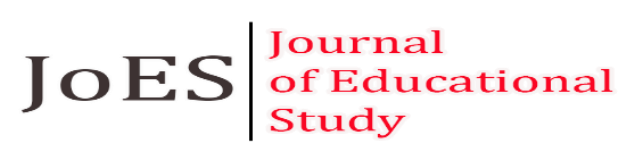

ISSN 2798-0650

Volume 1 Issue 32021

DOI: 10.36663/joes.v1i3.204

In conclusion, the teacher found that the quiet atmosphere provides a conducive environment that helps maintain the teachers' focus during remote English teaching activity. Those findings are the result of the teachers' interview to investigate the limiting and supporting factors during remote teaching based on the teachers' perspective. It can be seen that the problem that appears during remote English teaching were not only from the connection problem. The teachers generally had a good connection for teaching at their home, but sometimes it was interrupted by bad weather. The teachers also find it difficult to choose a suitable learning model for the students because the teachers were not facing their students in the face-to-face meeting. However, the teachers were not found it difficult to conducting teaching and learning activity because the conducive environment support them to be more focus in delivering the material.

\section{Discussions}

The first aspect discussed in this research is the readiness level of the teachers at SMAN 1 Kubutambahan toward Remote English teaching. The mean score of the readiness level was 66.75, and it was in the interval $66.66<\mathrm{M}<79.99$ which shows that the teachers were in the ready category. Based on the result, it can be inferred that English teachers at SMAN 1 Kubutambahan were ready to conduct remote English teaching. The result was generally analysed based on the four dimensions from Aydin and Tasci (2005), namely technology, innovation, people, and selfdevelopment, which showed that the teachers were ready to conduct remote English teaching based on those four dimensions.

The second finding discussed is the teachers' readiness level toward Remote English teaching regarding to technology dimension. The technology dimension focuses on the teachers' ability and attitude toward technology used during remote English teaching. Based on the technology dimension, it was found that the English teachers at SMAN 1 Kubutambahan are able to use technology and Learning Management System (LMS) for teaching through the virtual class. It was shown that the mean score of the teacher in the technology dimension was 35.25, which categorized in the ready category, and it was in the interval $33.33<\mathrm{M}<39.99$. It means that teachers were ready in conducting remote teaching regarding to technology dimension. However, there was a minor problem where the teacher sometimes found a connection problem which makes the learning process interrupted. This finding is closely related to Lee et al.(2017) and Kaharuddin et al. (2020), which stated that teachers are required to master the technology used for learning, such as the computers, smartphone, and LMS for teaching since remote teaching processes count on the ability of the teacher in using the technology for teaching. Since the technology also needs a good connection, the connection problem sometimes interrupts the Remote English teaching process. This finding also relates to Fauzi et al.'s (2020) statement, which stated that some factors should be considered in conducting remote teaching, such as the internet connection and the facilitation. Therefore, when the teachers had a bad connection, the teaching and learning activity would be interrupted as well.

The third finding discussed is the readiness level of English teachers toward Remote English teaching based on the innovation dimension. The innovation dimension focuses on the teachers' 


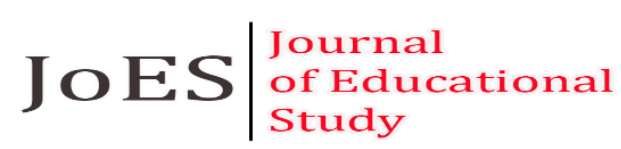

\section{ISSN 2798-0650 \\ Volume 1 Issue 32021 \\ DOI: 10.36663/joes.v1i3.204}

readiness to adopt innovation and openness to innovation. Based on the innovation dimension, it was found that the teachers were in the ready category within the interval $13.34<\mathrm{M}<16$, with the mean score was 13.75 . It means that the teachers were ready in adopting the innovation and had an openness toward innovation. Even though the teachers were considered in the ready category, the teachers still found a problem while conducting the remote teaching. It was shown from the interview result, which purposed to investigate the limiting factors of remote teaching. The result showed that the teachers were found it difficult to offer suitable learning models for the students because of the change from face-to-face learning to the full-virtual class. This finding is similar to a result of a study conducted by K. Lee (2020), which showed that the teachers found that being pedagogically innovative in virtual class is challenging for the teacher because of the limitation in interaction with the students that caused it difficult to choose the learning material. These findings are related to Sun (2011) which states that required the teacher to transfer all of the material and source into the online platforms, which require teachers' ability to adopt the innovation.

The fourth aspect discussed is the teachers' readiness toward remote English teaching based on the people dimension. People dimension concern in teachers' experience and ability in using and accepting technology for learning. Based on the people dimension, it was found that the English teachers at SMAN 1 Kubutambahan were categorized in the quite ready category within the interval $8<\mathrm{M}<10$ since the mean score was 8.50. From the result, it can be inferred that the teachers were able to use and accept the technology used for Remote English teaching. Even though the result showed that the teachers were categorized as ready, they still found it difficult to adapt from face-to-face learning to a full virtual classroom. It supported by the interview result, which showed that the teachers found it difficult to conduct remote English teaching in the beginning because they were not have experienced the full-virtual classroom. The finding is slightly similar to a study conducted by Khatoony and Nezhadmehr (2020), which shows that the teachers found it difficult to adapt from the face-to-face classroom. It was caused by their lack of appropriate materials and demotivation toward virtual classroom due to their lack of experience in teaching virtual classroom. It is related to Rogers (2003), which state that teachers' experience and ability in accepting and using technology can affect their readiness level.

The fifth aspect discussed is teachers' readiness toward Remote English teaching based on the self-development dimension. Self-development dimension concern with teachers' ability in managing their time for their self-development and teachers' belief in self-development. The readiness level of the teachers was in the ready category with the mean score was 10.25 within the interval $10<\mathrm{M}<12$. The result showed that the English teachers at SMAN 1 Kubutambahan were able to manage their time for self-development and believe in self-development, which means that the teachers were ready to conduct remote English teaching. This result also supported the interview result, which shows that the teachers experienced some workshops for teaching the fullvirtual class. This finding is slightly similar to Gao and Zhang's (2020) findings. The English teacher deals with the challenges during teaching and learning activities through teaching practices and understanding students' needs by attending workshops or teaching practices. These findings are related to Aydın and Tasci's (2005) opinion, which stated that the readiness level is affected by how much people are motivated to develop themselves and adapt to the new situation. By 


\section{JOES $\mid \begin{aligned} & \text { Journal } \\ & \text { of Educational } \\ & \text { Study }\end{aligned}$}

ISSN 2798-0650

Volume 1 Issue 32021

DOI: $10.36663 /$ joes.v1i3.204

experiencing the workshop, it means that the teachers were aware of their self-development which affect their readiness level.

For the implication of this study, the English teachers' readiness level is in the ready category, and the students' readiness level is in the quite ready category. It means that the student's readiness level needs to be improved to make remote English teaching more effective. This result is obtained since both the English teachers and students were facing some limiting factors during remote English teaching, such as connection problems, choosing suitable learning models, and learning environment problems. Based on those results, the teachers can improve the readiness by attending some workshops that trained and prepared English teachers to adjust the material and choose the suitable learning model. The students need to be more familiar with the circumstance of Remote English teaching to gain their learning motivation, even they have to learn under a bad circumstance due to the connection and environmental problem. The government also needs to improve the readiness level, especially students' readiness level, by providing equal infrastructure in remote areas. Furthermore, this result can be used as the evaluation for both teachers and students to improve their readiness level in remote English teaching context.

\section{Conclusions and Suggestions}

This study has several aims, namely: (1) To investigate the readiness level of the English teachers and students at SMAN 1 Kubutambahan toward Remote English teaching context and (2) To investigate the limiting and supporting factors both from English teachers' and students' perspective. This study used the explanatory sequential mixed-method, combining the quantitative and qualitative data to be collected and analyzed as the result of this study. This study took place at SMAN 1 Kubutambahan, Buleleng regency, which is chosen as the setting because this high school implements remote teaching without having experienced remote teaching before the pandemic. The readiness level of the English teachers and students toward remote English teaching, and the limiting and supporting factors in Remote English teaching are not yet identified. Thus, this research was conducted to investigate the readiness level of the English teachers and students at SMAN 1 Kubutambahan toward the remote English teaching context. Further, this research also investigates the limiting and supporting factors from English teachers' and students' perspectives.

Regarding to the result of the questionnaire and interview, it was found that English teachers at SMAN 1 Kubutambahan were categorized in the ready category in conducting the remote teaching. The result gained based on the analysis of four dimensions used in this research. It means that the English teachers were ready to conduct remote English teaching based on those four dimensions. Additionally, there are limiting factors that limit the English teachers in remote teaching. The limiting factors for the English teachers came from their ability to choose these suitable learning models for the students. However, some supporting factors assist the English teachers and the students during remote teaching, such as the conductive environment and assistance in the form of internet quotas from the government. After conducting this study, there are some suggestions given from the result of this study. It is suggested for the students to see the 


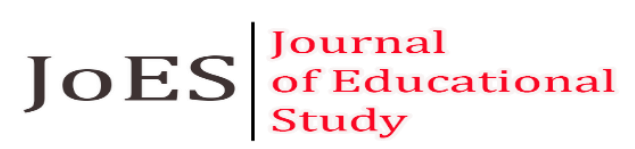

ISSN 2798-0650

Volume 1 Issue 32021

DOI: $10.36663 /$ joes.v1i3.204

benefits of remote English teaching to help the students to improve their motivation during remote teaching. It is suggested for the teachers to take the result as an evaluation to conduct meaningful remote teaching. Other researchers suggested continuing this research by conducting another descriptive study as a comparison for this study.

\section{References}

Ahmad, J. (2012). English Language Teaching ( ELT ) and Integration of Media Technology. Procedia - Social and Behavioral Sciences, 47(Balaaco 1996), 924-929. https://doi.org/10.1016/j.sbspro.2012.06.758

Atmojo, A. E. P., \& Nugroho, A. (2020). EFL Classes Must Go Online! Teaching Activities and Challenges during COVID-19 Pandemic in Indonesia. Register Journal, 13(1), 49-76. https://doi.org/10.18326/rgt.v13i1.49-76

Aydın, C. H., \& Tasci, D. (2005). International Forum of Educational Technology \& Society Measuring Readiness for e-Learning: Reflections from an Emerging Country Published by: International Forum of Educational Technology \& Society Linked references are available on JSTOR for this arti. 8(4), 244-257.Baran, E., Correia, A. P., \& Thompson, A. (2011). Transforming Online Teaching Practice: Critical Analysis of The Literature on The Roles and Competencies of Online Teachers. Distance Education, 32(3), 421-439. https://doi.org/10.1080/01587919.2011.610293

Besser, A., Flett, G. L., \& Zeigler-Hill, V. (2020). Adaptability to a sudden transition to online learning during the COVID-19 pandemic: Understanding the challenges for students. Scholarship of Teaching and Learning in Psychology. https://doi.org/10.1037/st10000198

Champa, R. A., Rochsantiningsih, D., \& Kristiana, D. (2019). Teachers' Readiness Indicators on ICT Integration into Their Teaching. Budapest International Research and Critics in Linguistics and Education (BirLE) Journal, 2(4), 195-203. https://doi.org/10.33258/birle.v2i4.508

Churiyah, M., Sholikhan, S., Filianti, F., \& Sakdiyyah, D. A. (2020). Indonesia Education Readiness Conducting Distance Learning in Covid-19 Pandemic Situation. International Journal of Multicultural and Multireligious Understanding, 7(6), 491. https://doi.org/10.18415/ijmmu.v7i6.1833

Fauzi, I., \& Sastra Khusuma, I. H. (2020). Teachers' Elementary School in Online Learning of COVID-19 Pandemic Conditions. Jurnal Iqra': Kajian Ilmu Pendidikan, 5(1), 58-70. https://doi.org/10.25217/ji.v5i1.914

Gao, L. X., \& Zhang, L. J. (2020). Teacher Learning in Difficult Times: Examining Foreign Language Teachers' Cognitions About Online Teaching to Tide Over COVID-19. Frontiers in Psychology, 11(September), 1-14. https://doi.org/10.3389/fpsyg.2020.549653

Hung, M. L. (2016). Teacher Readiness for Online Learning: Scale development and teacher perceptions. Computers and Education, 94, 120-133. https://doi.org/10.1016/j.compedu.2015.11.012

Kaharuddin, Djuwairiah Ahmad, M., \& Rusni. (2020). Contributions of technology, culture, and attitude to English learning motivation during COVID -19 outbreaks. Systematic Reviews in Pharmacy, 11(11), 76-84. https://doi.org/10.31838/srp.2020.11.13 


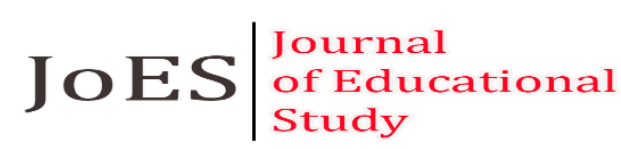

ISSN 2798-0650

Volume 1 Issue 32021

DOI: $10.36663 /$ joes.v1i3.204

Khatoony, S., \& Nezhadmehr, M. (2020). EFL Teachers' Challenges in Integration of Technology for Online Classrooms During Coronavirus (COVID-19) Pandemic in Iran. AJELP: Asian Journal of English Language and Pedagogy, 8(2), 1-16. https://ojs.upsi.edu.my/index.php/AJELP/article/view/3523

Laal, M., Laal, M., \& Kermanshahi, Z. K. (2012). 21st Century Learning; Learning in Collaboration. Procedia - Social and Behavioral Sciences, 47, 1696-1701. https://doi.org/10.1016/j.sbspro.2012.06.885

Lee, C., Yeung, A. S., \& Ip, T. (2017). University english language learners' readiness to use computer technology for self-directed learning. System, 67, 99-110. https://doi.org/10.1016/j.system.2017.05.001

Lee, K. (2020). Openness and innovation in online higher education: a historical review of the two discourses. Open Learning: The Journal of Open, Distance and e-Learning, 00(00), 1-21. https://doi.org/10.1080/02680513.2020.1713737

Lowenthal, P., Bauer, C., \& Chen, K. Z. (2015). Student Perceptions of Online Learning: An Analysis of Online Course Evaluations. American Journal of Distance Education, 29(2), 8597. https://doi.org/10.1080/08923647.2015.1023621

Martiana, N. (2019). Challenges of Teaching English With Its Four Language Skills In A Rural School Of West Kalimantan. 1937(October).

Nicklin, J. M., McNall, L. A., Cerasoli, C. P., Varga, C. M., \& McGivney, R. J. (2016). Teaching Online: Applying Need Theory to the Work-Family Interface. American Journal of Distance Education, 30(3), 167-179. https://doi.org/10.1080/08923647.2016.1187042

Nugroho, A., \& Atmojo, A. E. P. (2020). Digital Learning of English Beyond Classroom: EFL Learners' Perception and Teaching Activities. Journal of English Education and Linguistics Studies, 2019, 219-243.

Rogers, E. M. (2003). Diffusion of Innovations, 5th Edition. Free Press.

Shearer, R. L., Gregg, A., \& Joo, K. P. (2015). Deep Learning in Distance Education: Are We Achieving the Goal? American Journal of Distance Education, 29(2), 126-134. https://doi.org/10.1080/08923647.2015.1023637

Sun, S. Y. H. (2011). Online Language Teaching: The Pedagogical Challenges. Knowledge Management and E-Learning, 3(3), 428-447. https://doi.org/10.34105/j.kmel.2011.03.030

Tejedor, S., Cervi, L., Pérez-Escoda, A., Tusa, F., \& Parola, A. (2021). Higher Education Response in the Time of Coronavirus: Perceptions of Teachers and Students, and Open Innovation. Journal of Open Innovation: Technology, Market, and Complexity, 7(1), 1-15. https://doi.org/10.3390/joitmc7010043

Widodo, A., Nursaptini, N., Novitasari, S., Sutisna, D., \& Umar, U. (2020). From Face-to-Face Learning to Web Base Learning: How Are Student Readiness? Premiere Educandum : Jurnal Pendidikan Dasar Dan Pembelajaran, 10(2), 149. https://doi.org/10.25273/pe.v10i2.6801

Widyanti, A., \& Park, J. (2020). e-Learning Readiness and Perceived Learning Workload Among Students in an Indonesian University. Knowledge Management \& E-Learning: An International Journal, 12(1), 18-29. https://doi.org/10.34105/j.kmel.2020.12.002

Young, S. (2010). American Journal of Distance Student Views of Effective Online Teaching in Higher Education. December 2014, 37-41. https://doi.org/10.1207/s15389286ajde2002 